EarthArXiv coversheet for:

\title{
Reactionary fence installation for post-Superstorm Sandy dune recovery
}

Bianca R. Charbonneau ${ }^{*} 1,2$ and John P. Wnek ${ }^{3}$

1 Department of Biology, Villanova University, Villanova, PA 19085

2 Biology Department, University of Pennsylvania, 433 South University Ave, 330A Leidy Labs, Philadelphia, PA 19104-4544

3 Marine Academy of Technology and Environmental Science, Manahawkin, NJ 08050

*Corresponding author: binoink@gmail.com (email) @thedunegoon (Twitter \& Instagram) www.thedunegoon.weebly.com (website)

This article is a postprint from Shore \& Beach, published by ASBPA. Shore \& Beach authors retain copyright over their work, and the journal also permits the distribution of typeset manuscripts (this was confirmed with the editor).

Shore \& Beach does not mint DOls, therefore citation of this article should us the EarthArXiv $\mathrm{DOI}$ appended to the following citation:

Charbonneau BR and Wnek JP (2016), Reactionary fence installation for post-Superstorm Sandy dune recovery, Shore \& Beach, Vol. 84, No. 3, p42-48<EarthArXiv DOI> 


\title{
Reactionary fence installation for post-Superstorm Sandy dune recovery
}

\author{
By \\ Bianca Reo Charbonneau ${ }^{1,2}$ and John P. Wnek ${ }^{3}$ \\ ${ }^{1}$ Department of Biology, Villanova University, Villanova, PA 19085 \\ ${ }^{2}$ Department of Biology, University of Pennsylvania, Philadelphia, PA 19104 \\ ${ }^{3}$ Marine Academy of Technology and Environmental Science, Manahawkin, NJ 08050 \\ Contact: Bianca Reo Charbonneau \\ University of Pennsylvania, 103 Leidy Labs, 3740 Hamilton Walk, Philadelphia, PA 19104-6018 \\ Tel: (973)879-2856•E-mail: BCharbon@sas.upenn.edu
}

\begin{abstract}
Dunes are invaluable to coastal areas as dynamic buffers to erosion during high tides and storms, but do not accrue naturally in developed areas without assistance. Wood paling fencing is commonly used to cultivate dune development and thereby increase the protection afforded to coastal areas. In 2012, Superstorm Sandy devastated the mid-Atlantic, especially New Jersey where many areas are still recovering. At Island Beach State Park, NJ, parts of the primary dune system were destroyed and efforts were made to rebuild these areas as an emergency response. These efforts consisted of the installation of fencing in straight and zigzag patterns to catch-windblown sand and rebuild dunes. We collected field measurements of the short-term vertical sand accretion of recovering fenced localities and non-destroyed established dunes receiving no management intervention. We also collected $1.5 \mathrm{~m}$ cores to examine particle size after sieving in a Ro-Tap cascade shaker. There was high stochasticity among weekly changes in dune height and fence configuration affected growth rates. Zigzag fenced areas increased in height over time whereas straight fenced dunes did not. The sand composition of the dunes varied with height such that coarse sand decreased with height whereas finer sediments increased. At the initial stage of recovery fencing configuration seems to be an important factor in determining dune growth and assessing particle size can give insight into the means of sand transport. These results have implications for coastal management and restoration aimed at accruing the most sand in least time for immediate post-storm recovery efforts.
\end{abstract}

$\mathrm{T}$ Though dunes are invaluable natural resources that are integral components of healthy coastal systems, coastal squeeze and development have diminished their extent and made management of these areas necessary as opposed to supplementary (Elko et al. 2016). Coastal areas worldwide are the most vulnerable to the effects of climate change (Luettich et al. 2014) and as a result, coastal management will become more difficult in the years to come with the increase in the frequency, severity, and unpredictability of natural disturbances (Mann and Emanuel 2006; Miller et al. 2013). Dunes are ecologically important habitat areas (Freestone and Nordstrom 2001; Saye et al. 2005) with high relevance for economies and shoreline stability; they are dynamic buffers to erosion, protecting upland areas during high tides and storms (Nordstrom and Jackson 2013). As the interface between land and sea, our coasts are inherently geologically unstable and dunes are in a dynamic equilibrium, constantly shifting between periods of erosion and accretion. This equilibrium can shift from more erosional to more depositional at any site and between sites depending on conditions such as sediment supply and obstruction on the beach surface (Hsu and Weggel 2002; Doody 2012) which play a role in contributing to the inherent variability within and among dune systems (Houser et al. 2008; Houser and Mathew 2011). Although there is a diverse array of manmade protective structures that can buffer our coasts, these ultimately reduce the resiliency of the areas they intend to protect whereas continuous dunes are more resilient to short-term storm dam-
ADDITIONAL KEYWORDS: Coastal management, dune restoration, dune fencing, dune accretion, emergency response, Superstorm Sandy, barrier islands, fencing configuration.

Manuscript submitted 29 February 2016; revised and accepted 19 June 2016.

age and long-term erosion (Cooper and Pethick 2005).

With wind and a sand source, a dune will form if there is also an obstruction, natural (i.e. plants and wrack; Castro 1995) or manmade (i.e. fencing; Savage 1962; Mendelssohn et al. 1991; Miller et al. 2001). However, dunes tend not to not accrue naturally on developed beaches due to activities that remove obstructions (sand raking) and a lack of sediment as many beaches are eroding. Thus, installing wood paling fences and planting dune-building grasses along supra-tidal areas are common and necessary management methods to build and maintain a dune. To save on fencing costs, coastal managers have attempted to use synthetic fabrics instead of wood, but over time these deteriorate and cause the dune to collapse (Miller et al. 2001). It is important to consider fence configuration prior to installation as different orientations have the potential to increase accretion rates. However, the increased surface area of some configurations, such as spurred (continuously parallel to the shore with perpendicular short segments evenly spaced) and zigzag (continuous fencing at $45^{\circ}$ ), does not always result in faster accretion than traditional straight fencing 
parallel to the beach (Savage 1962; Miller et al. 2001). Similarly, zigzag and spurred patterns initially accrue sand at high rates, but after three years, straight configuration exceeded all others (Mendelssohn et al. 1991). There is debate over the cost-benefit of different configurations for management, but it is clear that there is no accretion without fence or plant aid on recreational beaches due to the interference of anthropogenic activities.

Vegetation can be as effective as fencing and has the added advantage of continuing to accumulate and grow vertically in time with the dune (Miller et al. 2001). However, anthropogenic effects on recreational beaches, such as foot-traffic and pollution, often prevent vegetation from successfully colonizing barren foreshore areas naturally. As a result, communities engage in dune grass planting events and planting guidelines often vary by town and state. By planting vegetation, a dune can become a functioning ecosystem as well as a more stable protective structure (Freestone and Nordstrom 2001). The roots of grasses such as native American beachgrass (Ammophila breviligulata) provide the dune with necessary structural support by binding sand and thereby holding mature dunes intact (Silva et al. 2016), but vegetation may play a minimal role in the initial accretion of nascent dunes, newly formed, compared to fences (Mendelssohn et al. 1991).

Dune maintenance can be cumbersome, but is paramount for the protection and safety of densely populated and inherently geologically unstable coastal communities worldwide; this is especially true in New Jersey, which is home to the first recreationally and commercially developed coastline and today boasts the most developed and densely populated coastline in the United States (U.S. Census 2010). When large-scale storms, such as Superstorm Sandy (October 2012) — the most physically and economically impactful hurricane to the mid-Atlantic region in decades (Cuomo 2012) - occur, dune and subsequent upland damage can be inevitable. However, coastal communities that think ahead and preserve and care for dunes years prior to storms suffer less in damages than towns that do not (Nuwer 2012); thus, emphasizing the importance of dunes for protecting infrastructure in developed coastal areas.

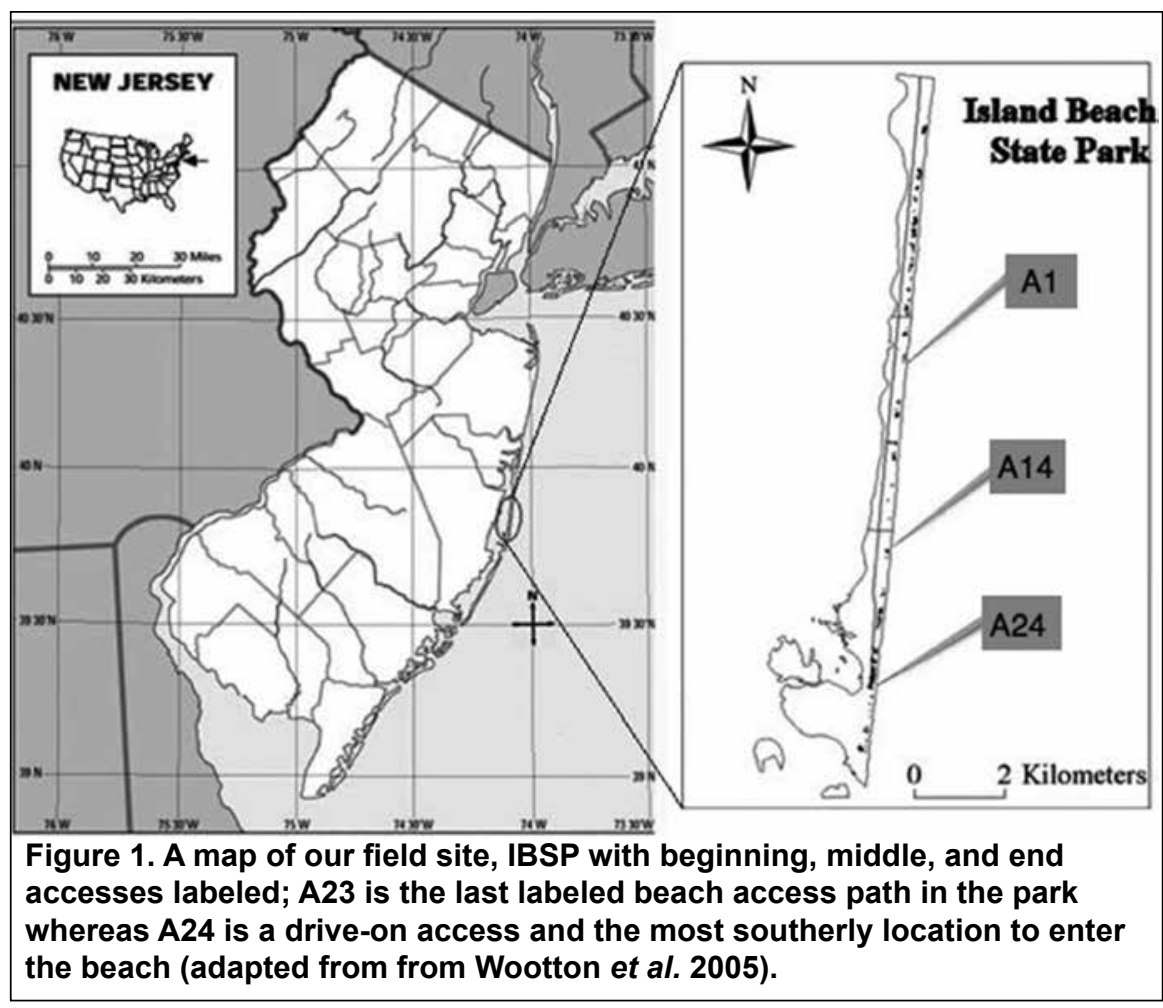

The recovery of New Jersey coastal ecosystems after Superstorm Sandy afforded the opportunity to examine dune growth from a baseline of zero. This study is a quantification of dune growth over time as a result of emergency fencing restoration efforts post-Sandy at Island Beach State Park (IBSP). Prior to Superstorm Sandy, the IBSP barrier island coast had been protected by largely continuous dunes, the longest stretch in New Jersey. We set out to test if: (1) areas being restored with fencing accrued sand at the same rate as non-destroyed natural dune areas without fencing; (2) dune accretion varied by fencing configuration, specifically zigzag or straight; and (3) grain sizes atop non-destroyed dunes and areas being restored with fencing differed. This study is short-term and focuses on the immediate accretion attained post-fencing installation and what configurations work to accrue the most sand in the least time for immediate poststorm recovery efforts.

\section{METHODS}

We collected our data at Island Beach State Park, Berkeley Township, Ocean County, NJ. The park is an approximately $16 \mathrm{~km}$ barrier island with sandy beach shoreline transitioning into a complex dune system spanning the full beach-dune successional gradient (first dune ridge to maritime forest) into tidal marsh. Precipitation and wind speeds along Barnegat
Bay are lowest seasonally April through August with prevailing winds from the southwest. Conversely, northerly winds and storms in the fall and winter seasons have the potential to cause erosion along the micro-tidal environment (tidal range $<0-2 \mathrm{~m}$ ). The park offers automobile beach access at four locations and has 23 public beach access areas with footpaths. We collected data along all accessible public beach accesses, A1-A23 ( $A=$ access; Figure 1). Sandy dissipated the primary dunes, the first dune ridge of the system, in the northern beach accesses, A2-A12. There are ongoing efforts to recover these now vulnerable areas which are referred to throughout this paper as "restoring dunes." During the duration of this study, restoring dunes were accruing sand aided by paling snow fences in straight or zigzag configurations during our collections. The primary dunes in the southernmost part of the park A15-A24 were eroded, but the system progression, primary to secondary and tertiary dunes and maritime forest with characteristic successional changes in vegetation remains intact such that average height of the crest is $3.74 \mathrm{~m} \pm 0.86 \mathrm{~m} \mathrm{SD}$; these areas will henceforth be referred to as "established dunes." A13-A14 and A1 are unique transition areas whereby parts of dune system were washed-out and are being restored, but the area is still sprinkled with lone standing established dunes that were not destroyed. 
Table 1. Abiotic conditions during our study period. All values are the average of the measures taken from NOAA Buoy \#44091 the day prior to and morning of each weekly measurement.

\begin{tabular}{lllll}
\hline Week & $\begin{array}{l}\text { Wind direction } \\
\text { (degrees) }\end{array}$ & $\begin{array}{l}\text { Prevailing } \\
\text { wind direction }\end{array}$ & $\begin{array}{l}\text { Wind } \\
\text { speed }(\mathrm{m} / \mathrm{s})\end{array}$ & $\begin{array}{l}\text { Wave } \\
\text { height }(\mathrm{m})\end{array}$ \\
1 & $130^{\circ}$ & $\mathrm{SE}$ & 1.94 & 0.24 \\
2 & $56.67^{\circ}$ & $\mathrm{NE}$ & 4.17 & 0.2 \\
3 & $292^{\circ}$ & $\mathrm{NW}$ & 3.84 & 39.72 \\
4 & $161^{\circ}$ & $\mathrm{SE}$ & 3.84 & 39.9 \\
5 & $43.75^{\circ}$ & $\mathrm{NE}$ & 4.375 & 0.6 \\
6 & $110^{\circ}$ & $\mathrm{SE}$ & 3.13 & 74.33 \\
7 & $85^{\circ}$ & $\mathrm{E}$ & 1.55 & 1.65 \\
8 & $64^{\circ}$ & $\mathrm{NE}$ & 2.86 & 0.3 \\
9 & $302.5^{\circ}$ & $\mathrm{NW}$ & 2.65 & 0.3 \\
10 & $156^{\circ}$ & $\mathrm{SE}$ & 2.12 & 0.3 \\
\hline
\end{tabular}

We were able to access and collect data from 19 of IBSP's 23 beach accesses at 43 dune localities. Of the four accesses not surveyed, A2 and A3 were inaccessible due to scarping and A17 and A22, were inaccessible due to piping plover (Charadrius melodus) nesting sites. The 43 localities (individual points along a dune), consist of 19 established dune localities and 24 restoring dune localities, the latter of which IBSP management had installed fencing at beach level as an emergency effort after Sandy during winter 2013. The fencing was traditional $1.27 \mathrm{~cm} \times 0.95 \mathrm{~cm} \times 1.22 \mathrm{~m}$ natural wood lathe slatted fencing, commonly used for snow and sand management supported by twisted wire, 0.5 strands of 14-gauge. Fencing configuration was continuous and in a straight (north to south orientation) or zigzag (fencing at a $45^{\circ}$ angles to the ocean). Throughout the park, there was more straight fencing than zigzag and zigzag was not evenly distributed, because of the higher price of installing zigzag fencing, which requires more time and fencing; this is represented in our sample sizes for restoring dune localities which contain 15 straight and 9 zigzag localities.

We collected data weekly for 10 weeks (4 June to 5 August 2013); collecting for a longer duration was not possible as the initial installation was done with emergency funds that were later unavailable to raise the covered fences or install new ones to allow for continued monitoring. During the duration of the study, average wind speed for Barnegat Bay was 3.67 $\mathrm{m} / \mathrm{s}$, wave height was $0.39 \mathrm{~m}$, and wind direction was $161.15^{\circ}$ (NOAA Buoy
\#44091). We sampled 1-3 localities per access based on access length, whereby longer accesses had more localities; all localities in a beach area were equidistant from one another and the southern-most and northern-most ends of the beach area. The average distance between localities was $109.6 \mathrm{~m}$, and all were a minimum of $33 \mathrm{~m}$ apart. At each locality we measured dune height and assessed vegetation weekly at a standard time and collected one core.

We measured dune height to assess sand accretion at each locality as a function of dune type, established or restoring and among the latter, zigzag or straight fence. At the toe of each dune, we used a Leupold 6x23 RX-600i Laser Rangefinder to measure the length of the foredune slope (toe to crest) and the angle of the slope using a clinometer. To account for the variability in dune height and development over short distances, we took these measurements at the initial marked point and $3.5 \mathrm{~m}$ to the left and right and averaged the values; we sampled at multiple points in a locality to account for localized variability within dune systems (Houser and Mathew 2011). We then used these values to infer height using trigonometry (Dune height $=$ Sin $\left(\right.$ Angle $\left._{\mathrm{AVG}}\right) \mathrm{x}$ slope length). We took measurements weekly from restoring dune localities, and every three weeks from established dunes which are more stable over time (Millington et al. 2009). We calculated net and weekly flux in height. Small errors in measures of slope angle will result in large changes in calculated height, especially in dunes with a longer foredune slope - we do not believe this to be a source of error in our study as foredune slopes were relatively short for our recovering dunes and averaging multiple angles per dune accounted for variability in height along the dune.

Lastly, we took cores to examine if sand grain size and thus texture varied as a function of locality type. We collected one vertical core from each locality using a standard metal coring device to extrude an unmixed and continuous $1.5 \mathrm{~m}$ core (Glew and Smol 2002). We took cores 1 $\mathrm{m}$ landward from established dune crests and adjacent to and abutting the landward side of the fence of restoring dunes. Ex situ, we oven-dried and mixed each core prior to sieving $100 \mathrm{~g}$ samples, using a RX-29 Ro-Tap cascade shaker. We sorted samples into silts and coarse, medium, fine, and very fine sands using eight U.S. Standard Sieve Mesh Sizes ranging from $0.71 \mathrm{~mm}$ to $>0.105 \mathrm{~mm}$ (Folk 1980) with sieve time standardized to $5 \mathrm{~min}$ as increasing time increases the effectiveness of sorting with added energy (Diaz-Zorita et al. 2007).

\section{STATISTICAL ANALYSES}

We used JMP Pro 11.0 to perform analyses. All tests are two-tailed using $\alpha=0.05$ as the threshold of significance and all means are reported \pm standard deviation. We used regression to examine average dune height as a function of time as well as to examine a relationship between wind and change in height in restoring dunes. Wind data is from offshore NOAA Buoy \#44091, we did not have anemometers throughout the park to measure wind at individual localities and thus assume uniform speed and direction along IBSP for analyses with wind. To look at the potential effect of location, we used Analysis of Variance (ANOVA) to compare the growth of restoring dune localities by beach access, holding time constant and regression of initial dune height as a function of growth rate. We compared mean initial and end dune heights using Student's t-tests. We also used Student's T-tests to analyze the composition of our cores, simplifying particle sizes to coarse (mesh \#25 and \#35), medium (mesh \#45 and \#60), fine (mesh \#70 and \#100), and very fine/silt (mesh \#140 and smaller).

\section{RESULTS}

The established dunes did not show significant change in height as a function of time $\left(\mathrm{R}^{2}=0.21 ; P=0.54\right)$, but restor- 
ing localities increased $\left(\mathrm{R}^{2}=0.54 ; P=\right.$ $0.01)$. This latter result is due to the sand accretion observed at zigzag localities. Examining the two restoring fence configurations revealed that straight fenced dunes did not change in height with time $\left(\mathrm{R}^{2}=0.00 ; P=0.87\right)$, but zigzag fenced localities increased $\left(\mathrm{R}^{2}=0.85 ; P\right.$ $=0.0001$; Figure 2).

Comparing start and end heights of dunes did not show a statistically significant increase in straight fence $\left(\bar{x}_{\text {Start }}=\right.$ $35.35 \mathrm{~cm} \pm 18.87 \mathrm{~cm} ; \bar{x}_{\text {end }}=44.91 \mathrm{~cm} \pm$ $\left.27.56 \mathrm{~cm} ; t_{25}=-1.11 ; P>0.20\right)$ or zigzag pattern $\left(\bar{x}_{\mathrm{Start}}=23.74 \mathrm{~cm} \pm 15.21 \mathrm{~cm}\right.$; $\bar{x}_{\text {end }}=34.45 \mathrm{~cm} \pm 16.5 \mathrm{~cm} ; t_{16}=-1.43$; $P=0.09$ ). Similarly, straight fence localities began at a greater relative starting (base to crest) height than zigzag $\left(\bar{x}_{\mathrm{S}}=\right.$ $35.35 \mathrm{~cm} \pm 18.87 \mathrm{~cm} ; \bar{x}_{\mathrm{zz}}=17.85 \mathrm{~cm}$ $\pm 14.52 \mathrm{~cm} ; t_{12}=-2.28 ; P<0.05$; Figure 2) such that comparing relative heights is not statistically appropriate. However, initial height did not affect restoring locality growth rates $\left(\mathrm{R}^{2}=0.00 ; P=0.96\right)$ and the initial height discrepancy was not a function of linear location, north to south, in the park $\left(\mathrm{R}^{2}=0.09 ; P=0.22\right)$. The previous two findings are supported by the fact that there were no differences in weekly changes as a function of access, i.e. location (ANOVA; $\mathrm{F}_{8,171}=0.10 ; P=$ 0.99 ). Restoring height change (i.e. accretion or erosion) from first to last collection did not vary by fence configuration $\left(\bar{x}=9.99 \mathrm{~cm} \pm 16.09 \mathrm{~cm} ; t_{18}=0.17 ; P\right.$ $=0.87$ ) and week to week, there were only significant differences in the height change of the two fence types during two collections: week two to three zigzag accumulated more sand than straight ( $\bar{x}_{\mathrm{S}}=-8.5 \mathrm{~cm} \pm 32.77 \mathrm{~cm} ; \bar{x}_{\mathrm{zz}}=13.48$ $\left.\mathrm{cm} \pm 12.59 \mathrm{~cm} ; t_{19}=2.21 ; P=0.04\right)$ and week nine to ten straight accrued more than zigzag $\left(\bar{x}_{\mathrm{S}}=-1.76 \mathrm{~cm} \pm 14.55 \mathrm{~cm}\right.$; $\bar{x}_{\mathrm{zz}}=-8.3 \mathrm{~cm} \pm 6.9 \mathrm{~cm} ; t_{19}=2.21 ; P=$ 0.04; Figure 3).

Change in height among restoring localities was unrelated to abiotic parameters of the study location. Wind speed was unrelated to height change $\left(\mathrm{R}^{2}=0.05 ; P\right.$ $=0.36$ ), as was wind direction split into North, South, East, and West based on degrees on a compass rose (ANOVA; $\mathrm{P}>0.05)$. Please see Table 1 for abiotic conditions (wind and waves) associated with Barnegat Bay during the length of the study. At the end of the study, three localities, two straight and one zigzag

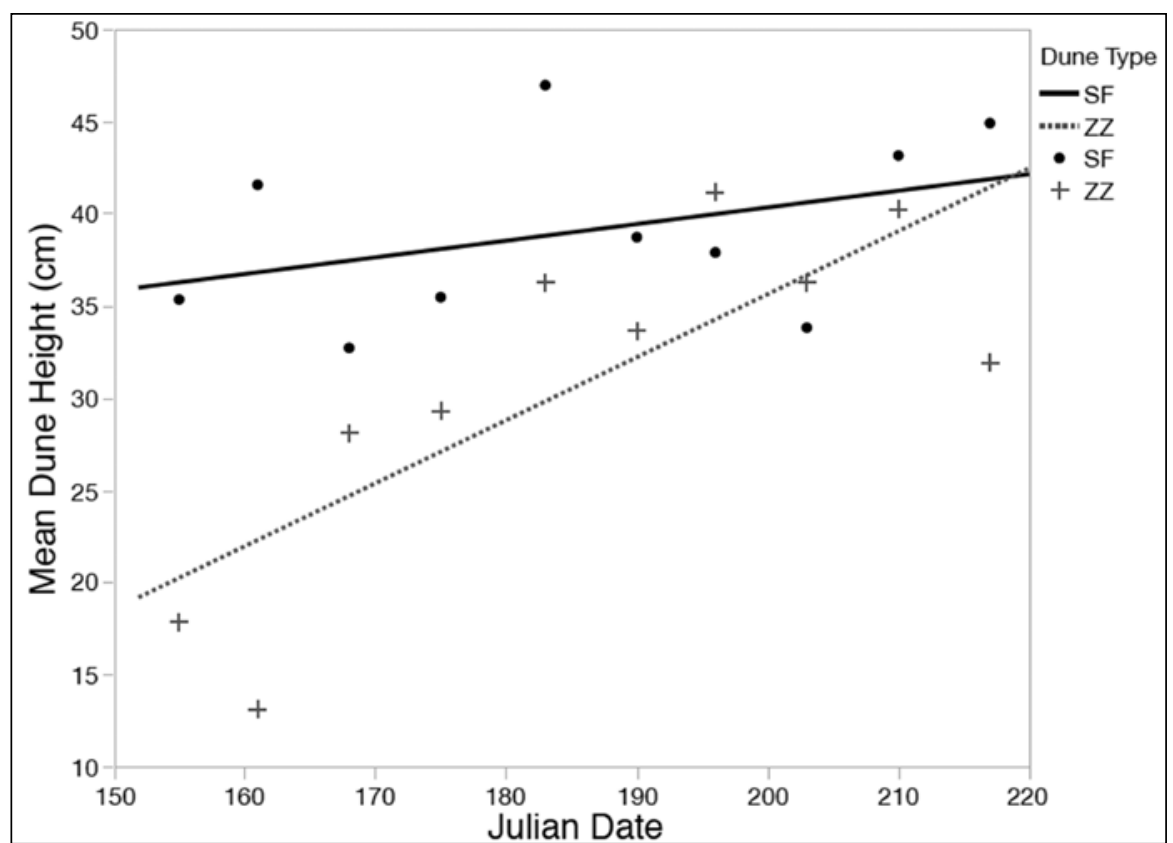

Figure 2. Of the two fence configurations, straight fenced (SF) dunes (solid line) did not increase significantly $\left(R^{2}=0.00 ; P=0.87\right)$, whereas zigzag $(Z Z)$ fences (dashed line) increased $\left(R^{2}=0.85 ; P=0.0001\right)$.

Figure 3. There was high variability among the mean changes observed in the two restoring dune types, straight fenced (SF, solid line) and zigzag (ZZ, dashed line) localities.

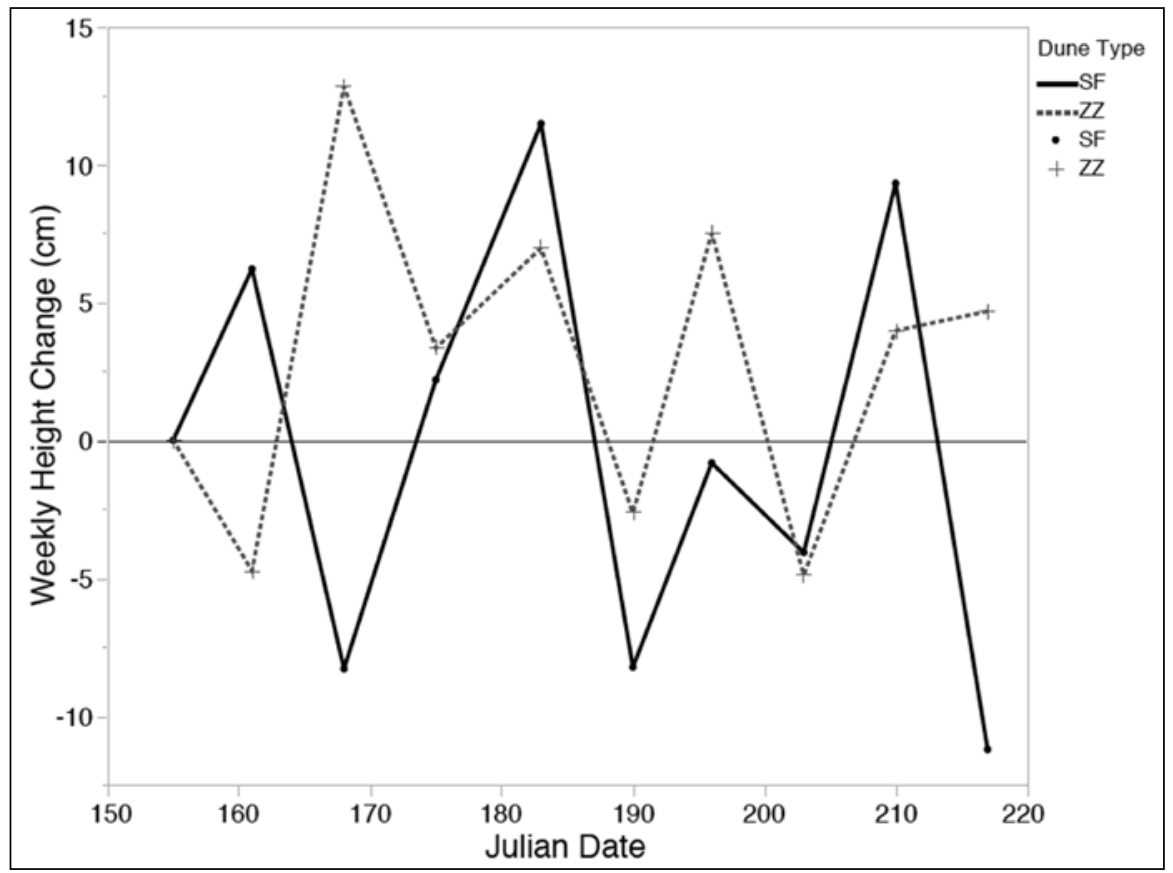

fenced, were almost completely buried (less than $15.2 \mathrm{~cm}$ of paling exposed).

There were no differences in the grain particle size between the two fence configurations $(P>0.05)$, but differences in sand composition by dune type and height. Restoring dunes were composed of a greater percentage of coarse sand ( $\bar{x}_{\mathrm{R}}=-21.63 \pm 9.31 ; \bar{x}_{\mathrm{H}}=12.31 \pm 10.95$; $t_{28}=2.55 ; P=0.009$ ) whereby established dunes are composed of more fine sand ( $\bar{x}_{\mathrm{R}}=-3.04 \pm 1.74 ; \bar{x}_{\mathrm{H}}=10.46 \pm 3.38 ; t_{21}$ $=-7.61 ; P<0.0001)$ and very fine sand $/$ silts $\left(\bar{x}_{\mathrm{R}}=-0.11 \pm 0.11 ; \bar{x}_{\mathrm{H}}=0.47 \pm\right.$ $0.14 ; t_{26}=-7.95 ; P<0.0001 ;$ Figure 4$)$ and did not differ in medium sand content $\left(\bar{x}_{\mathrm{R}}=-75.41 \pm 8.09 ; \bar{x}_{\mathrm{H}}=78.52 \pm 3.19\right.$; $\left.t_{20}=-1.42 ; P=0.17\right)$. These findings are supported by an observed positive relationship between average dune height and $\%$ very fine sand $\left(\mathrm{R}^{2}=0.76 ; P<0.0001\right)$ 


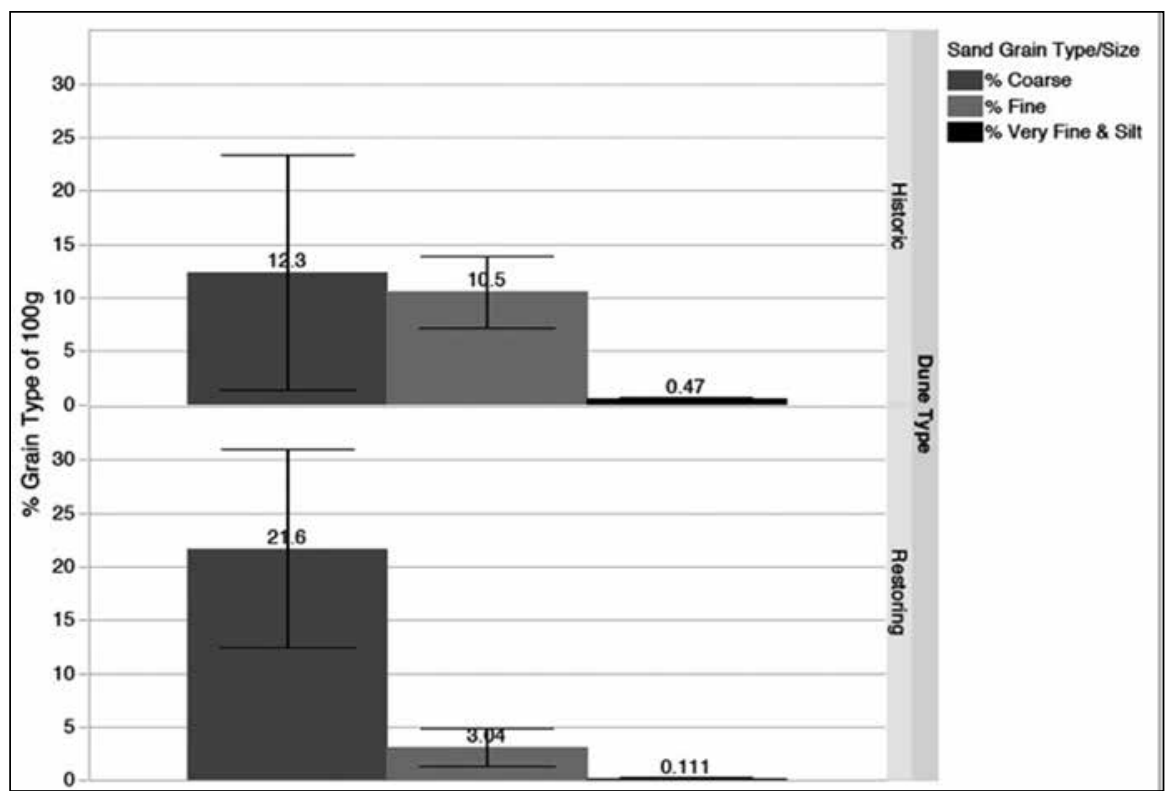

Figure 4. There were no differences in medium sand, but established dunes had greater fine $\left(t_{21}=-7.61 ; P<0.0001\right)$ and very fine/silts $\left(; t_{26}=-7.95\right.$; $P<0.0001)$ than restoring dunes. Restoring dunes had a greater proportion of coarse sands $\left(t_{28}=2.55 ; P=0.009\right)$. Error bars represent $+/$ - standard deviation.

Figure 5. Grain size composition changes as a function of dune height; medium, fine, and very fine sand increase with dune height whereas coarse sand decreases with rising dune crest height.

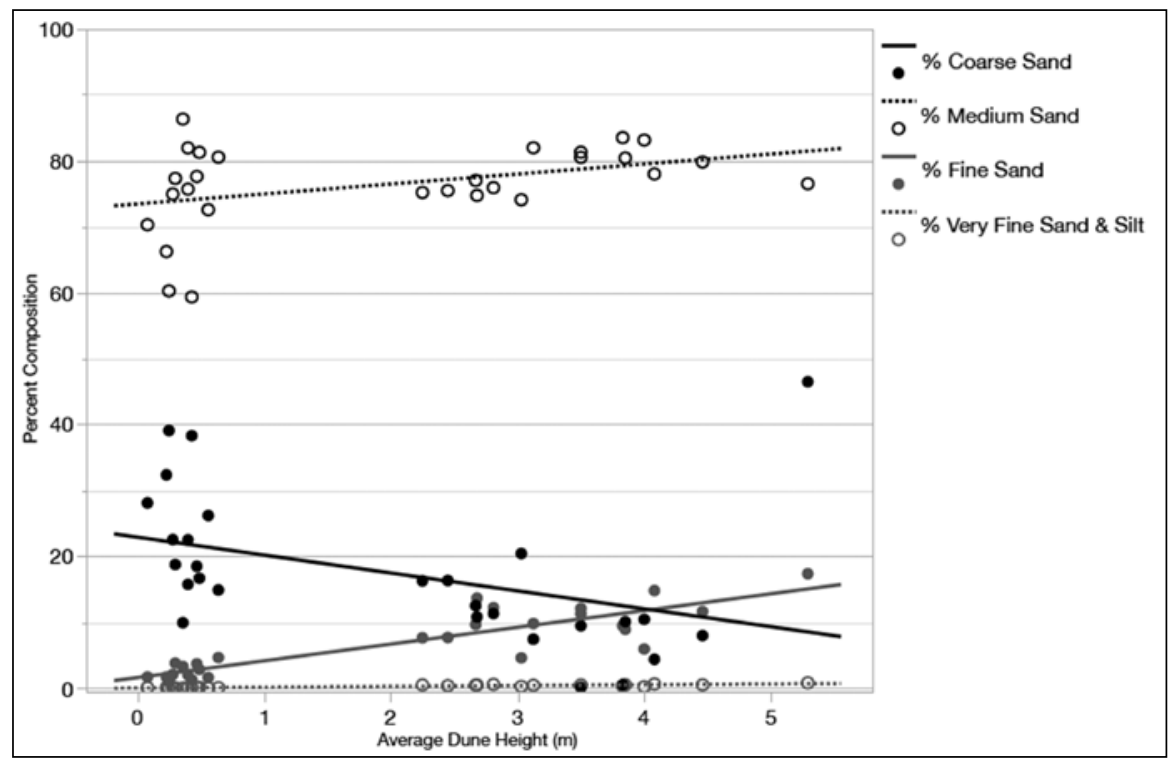

and $\%$ fine sand $\left(\mathrm{R}^{2}=0.75 ; P<0.0001\right)$, a positive trend for $\%$ medium sand $\left(\mathrm{R}^{2}\right.$ $=0.11 ; P=0.06)$, and negative relationship with $\%$ coarse sand $\left(\mathrm{R}^{2}=0.15 ; P=\right.$ 0.03; Figure 5).

\section{DISCUSSION}

When a community is recovering after a storm, there are many strategies and management options to consider (Cooper and Pethick 2005). Building dunes is one of the best solutions for restoration as it is nature-based, meaning it mimics the buffer system nature intended with minimal

synthetic and man-made elements. As a result, dunes are much less expensive than hard engineered structures (Harman et al. 2015). When using fencing to aid in dune growth, configuration should be considered from the perspective of cost, effectiveness, and implementation. The fences at IBSP were installed as an emergency response effort to begin recovery after Superstorm Sandy completely eroded the dunes of some areas of the park and different fence configurations were installed to note differences in initial accumulation rates. Based on our results, we recommend that a zigzag or similar pattern be used at the onset of restoration to aid in faster initial creation of nascent dunes; the dune is a phalanx defense line such that areas where a storm levels, breaches, or greatly erodes dunes renders these areas, and the upland areas that they buffer, vulnerable. Zigzag fence configuration increased dune height over time whereas straight fencing parallel to the shore remained statistically the same. There was noticeable accretion $(\approx 10 \mathrm{~cm}$ from week 1 to 10) over our study period though the change in start and end dune height for fence configurations did not reflect this.

Zigzag appears more effective at trapping sand in the short term than the traditional straight fence pattern; this result is likely due to increased surface area (Manohar and Bruun 1970) and angles to catch windblown sand, which should both increase accumulation. However, it is important to note that there may be no long-term differences in accumulation rates among configurations (Mendelssohn et al. 1991). Long-term rates were not tested, as there was no additional funding to raise or reinstall fences. Both fence configurations accrued sand such that while only three localities were covered and in need of reinstallation, many posts were close to $2 / 3$ covered - the point at which fencing should be lifted or reinstalled to continue to see growth (Savage and Woodhouse 1968). Once a fence is covered, if it is not lifted or additional fences added atop the old, then the accumulation rates are not sustained and eventually diminished (Dahl and Woodard 1977; Mendelssohn et al. 1991). This is important to note, as one could lose the progress and investment of time and money spent without continued management and monitoring of the fencing. Based on findings from this study, after the initial zigzag fencing is covered, we recommend reinstalling this configuration, or installing straight fence atop the older zigzag if funding is lacking.

There is currently a general lack of studies quantifying the effectiveness of fencing restoration efforts. Mendelssohn et al. (1991) found that zigzag and spurred fence configurations, in the first three years, accrued sand better than traditional straight fencing. However, straight fencing has also been documented as very effective (Woodhouse 1978; Anthony et al. 2007) and spurred and 
angled patterns have been documented as ineffective comparatively (Savage 1962; Knutson 1980; Miller et al. 2001). Varying configurations may be effective in some areas and not in others; based on sediment characteristics, fetch, and wind speed and direction, all of which can vary among and within a coastline locality (Hsu and Weggel 2002); these factors should be considered when making management decisions regarding configuration. To our knowledge, this is the first study to quantify short-term initial accretion of fence-aided dunes installed as an emergency response from a baseline of zero accumulation. Though it is difficult to compare our short-term findings to long-term studies, our findings are most consistent with Mendelssohn et al. (1991). Our study suggests that a zigzag fence configuration may work better in some areas at the onset of installation such that the more than $20 \%$ of additional cost factor associated with non-straight configurations could be argued as worth the added investment for more fencing (Knutson 1980).

It is difficult to compare and replicate fencing studies because of variable abiotic conditions and study durations at different sites and within sites. Other studies monitored dunes for a longer term, but collected less and more temporally spaced data (Savage 1962; Savage and Woodhouse 1968; Knutson 1980; Mendelssohn et al.1991; Miller et al. 2001). Our study was shorter term (i.e. three months), but is more comprehensive in documenting accretion, as we monitored weekly dune growth during a full summer season, which to our knowledge has not been previously carried out. Most dune erosion and accumulation occurs in the fall and winter months with storms and a seasonal shift in prevailing winds from southerly to northerly (Dolan and Davis 1992). Management focus is often long-term (over years and decades), for example it takes a dune planted with vegetation about seven years to become established (Maun 2009), but short-term changes (over months) or episodically with storms, ultimately direct the course of the long-term result. The long-term goal in coastal restoration is often to protect upland infrastructure and maintain beach width. Right after a storm, we want to do this in the most effective way to rebuffer an area with a dune more quickly and thus render it less vulnerable.
There were differences in the starting height and morphology of the restoring dunes, but this did not affect short-term growth rate. The starting height discrepancy, between straight and zigzag localities could be a function of: (1) localized variation in wind direction, wind speed, sediment size, and tidal fluctuations (Houser and Mathew 2011); (2) differences in beach width, as erosion is highest in narrower beach sections (Keijsers et al. 2014) and set-back distance from the ocean affects fencing success (Manohar and Bruun 1970; Hsu and Weggel 2002); (3) frequent changes in dune shape over time, which does not always reflect beach morphology (Saye et al. 2005); (4) small sample size; (5) variable storm impacts over short distances (Houser and Mathew 2011), for example, winter storms that occurred shortly after the fences were installed could have deposited sand unevenly along the park; or (6) variations in dune shape from accumulation patterns due to fence types, e.g. anecdotally zigzag localities collected sand in a mounded shape whereas straight fencing created a ramp like slope, an observation noted previously by Ruz and Anthony (2008) where straight fence height may not equate to sand volume and if so would be less effective in preventing dune overwash during storms.

There were differences in grain size between the restoring and established dunes. Restoring dunes were composed of a greater percentage of coarse sand and established dunes of greater fine and very fine sands and silts. Courser sand can be transported by tidal fluctuations during storms, as was the case with Hurricane Dennis and Katrina (Houser and Hamilton 2009). Winter storms that occurred after the installation of the fences likely distributed larger sediment particles to the restoring localities. We were not surprised that our established dunes had greater amounts of fine and very fine sands and silts, as we would expect the top layer of tall established dunes to be largely aeolian deposited. Coarser sand at restoring dune localities is likely also a function of the erosion incurred by Sandy, which eroded the dunes down to former high beach areas, which we would expect to have larger sand grain size. Coarser sand at restoring dune localities may also be indicative of a lack of retention of smaller particles by the fences alone. Vegetation can be very effective in aiding the dune growth vertically and horizontally (Knutson 1980) and planting vegetation can be as effective as fencing. However, accretion is often delayed at least a year as the plants become established (Mendelssohn et al. 1991) and fencing downwind of plants is superfluous; the plants will catch most of the sand (Savage and Woodhouse 1968). We recorded minimal vegetation establishment during our study and noted no difference in the appearance of restoring areas with $A$. breviligulata plugs planted behind them than those without.

While collecting our data, we encountered numerous forms of human disturbance that should be avoided, such as walking, trampling, and driving on dunes. Beach-goers may not recognize that the slopes in front of fencing are nascent dunes, as they do not yet possess "dunelike" characteristics, such as vegetation and or a clear crest and toe. Therefore, beach-goers may think the fencing is to keep them out of the area behind the barrier as opposed to off the area entirely. This notion requires further attention, but in the interim, signs can be effective at deterring foot traffic and should be installed (Gómez-Pina et al. 2002). String has also proved effective in protecting terrapin nesting areas, e.g. at A15, and could also be used to rope off dune toes. This action could result in public opposition as perceived beach space would be reduced, but could accelerate accretion by limiting anthropogenic effects that may slow the building process. These issues should be addressed to increase the effectiveness of fencing as a management tool.

\section{CONCLUSIONS}

In response to the need for short-term emergency efforts to rebuild after storm devastation, different fence configurations can result in varying short-term accretion rates. At Island Beach State Park, NJ, a zigzag fence configuration was more effective in the initial baseline period than traditional straight fence configuration. Further monitoring is needed to see if this finding persists longer-term in other seasons with changing abiotic conditions. Factors that were not considered are localized wind, sediment supply, beach width, and the possible effect of sandbar locations. Anthropogenic effects may have a strong influence on stability and should be minimized to increase the protection afforded by dunes. 
Dunes are critically important to protecting coastal communities. The results of this study have applications for coastal management and conservation in response to the need for short-term emergency efforts to rebuild after storm devastation. Enhancing the dune accretion process is becoming increasingly important in these inherently vulnerable and unstable coastal areas. Dunes will continue to be one of the best forms of defense against destructive abiotic factors. Their maintenance and restoration is essential for the continued maintenance of safe and well-fortified coastal communities.

\section{ACKNOWLEDGMENTS}

This work could not have been conducted without the co-operation and support of New Jersey Division of Parks and Forestry, Island Beach State Park, Park Manager Ray Bukowski, and Resource Interpretive Specialist Edward Hale. We wish to acknowledge Save Barnegat Bay and its Student Grant Program, the Marine Academy of Technology and Environmental Science (MATES) for allowing us to use their facilities and field resources throughout the study. We also wish to thank the Friends of Island Beach State Park for their generous funding of this study, and Professor James L. Gould of Princeton University for his pre-submission peer review of our paper.

\section{REFERENCES}

Anthony, E.J., S. Vanhee, and M.H. Ruz, 2007. “An Assessment of the impact of experimental brushwood fences on foredune sand accumulation basd on digital elevation models." Ecological Engineering 31(1): 41-46.

Castro, F., 1995. "Computer simulation of the dynamics of a dune system." Ecological Modelling 78: 205-217.

Cooper, N.J., and J.S. Pethick, 2005. "Sediment budget approach to addressing coastal erosion problmes in St. Ouen's Bay, Jersey, Channel Islands." J. Coastal Res., 21(1): 112-122.

Cuomo, A.M., 2012. "Governor Cuomo holds meeting with New York's Congressional Delegation, Mayor Bloomberg and regional county executives to review damage assessment for the state in wake of Hurricane Sandy." New York State. http://www.governor.ny.gov/ press/11262012-damageassessment. Accessed 20 September 2014.

Dahl, B.E., and D.W. Woodard, 1977. "Construction of Texas coastal foredunes with sea oats (Unicola paniculata) and bitter panicum (Panicum amarum)." International Journal Biometeorology 21(3): 267-275.

Diaz-Zorita, M., J.H. Grove, and E. Perfect, 2007. "Sieving duration and sieve loading impacts on dry soil fragment size distributions." Soil and Tillage Research 94:15-20.

Dolan R. and R.E. Davis, 1992. "An intensity scale for Atlantic Coast Northeast storms." J. Coastal Res., 8(4): 840-853.

Doody, J.P., 2012. Sand Dune Conservation, Management, and Restoration. Springer, New York.

Elko, N., K. Brodie, H. Stockdon, K. Nordstrom, C. Houser, K. McKenna, L. Moore, J. Rosati, P. Ruggierro, R. Thuman, and I. Walker, 2016. "Dune management challenges on developed coasts." Shore and Beach 84(1): 15-28.

Folk, R.L., 1980. Petrology of Sedimentary Rocks. Hemphill Publishing Company, Austin.

Freestone, A.L., and K.F. Nordstrom, 2001. "Early development of vegetation in restored dune plant microhabitats on a nourished beach at Ocean City, New Jersey." J. Coastal Conservation 7:105-116.

Glew, J.R., and J.P. Smol, 2002. "Sediment Core Collection and Extrusion." In: Last WM, Smol JP (eds) Tracking Environmental Change Using Lake Sediments. Kluwer Academic Publishers, New York, 73-105.

Gómez-Pina, G., J.J. Muñoz-Pérez, J.L. Ramírez, and C. Ley, 2002. "Sand dune management problems and techniques, Spain." In: Cooper, A., Jackson, D. (eds) International Coastal Symposium 2002 Proceedings, J Coastal Res. Spec. Issue 36:325-332.

Harman, B.P., S. Heyenga, B.M. Taylor, and C.S. Fletcher, 2015. "Global lessons for adapting coastal communities to protect against storm surge inundation." J. Coastal Res., 31(4): 790-801.

Houser, C., C. Hapke, and S. Hamilton, 2008. "Controls on coastal dune morphology, shoreline erosion and barrier island response to extreme storms." Geomorphology 100: 223-240.

Houser, C., and S. Hamilton, 2009. "Sensitivity of post-hurricane beach and dune recovery to event frequency." Earth Surface Processes and Landforms, 34(5): 613-628.

Houser, C., and S. Mathew, 2011. "Alongshore variation in foredune height in response to transport potential and sediment supply: South Padre Island, Texas." Geomorphology, 125(1):62-72.

Hsu, S.A., and J.R. Weggel, 2002. "Wind-Blown Sediment Transport," U.S. Army Corps of Engineers Coastal Engineering Manual (EM 1110-2-1100) Dept. of the Army, April $2002,79 \mathrm{p}$.

Keijsers, J.G.S., A. Poortinga, M.J.P.M. Riksen, and J. Maroulis, 2014. "Spatio-Temporal Variability in Accretion and Erosion of Coastal Foredunes in the Netherlands: Regional Climate and Local Topography." PLoS One 9(3): e91115.

Knutson, P.L., 1980. "Experimental dune restoration and stabilization. Nauset Beach, Cape Cod, Massachusetts." TP 80-5. U.S. Army Corps of Engineers, Coastal Engineering Research Center, Fort Belvoir, Virginia.

Leuttich, R.A., G.B. Baecher, S.B. Bell, P.R. Berke, R.B. Corotis, D.T. Cox, R.A. Dalrymple, T. MacDonald, K.F. Nordstrom, S. Polasky, S.P. Powers, D. Resio, and A. van Dongeren, 2014. Reducing Coastal Risk on the East and Gulf Coasts. The National Academies Press, Washington.

Mann, M.E. and K.A. Emanuel, 2006. "Atlantic hurricane trends linked to climate change." Earth and Space Science News 87(24): 233-244.

Manohar, M., and P. Bruun, 1970. "Mechanics of
Dune Growth by Sand Fences." The Dock \& Harbor Authority. Vol. L1(600): 1-10.

Maun, M.A., 2009. The biology of coastal sand dunes. Oxford: Oxford University Press.

Mendelssohn, I.A., M.W. Hester, F.J. Monteferrante, and F. Talbot, 1991. "Experimental dune building and vegetative stabilization in a sand-deficient barrier island setting on the Louisianna coast, USA." J. Coastal Res., 7(1):137-149.

Miller, D.L., M. Thetford, and L. Yager, 2001. "Evaluation of sand fence and vegetation for dune building following overwash by Hurricane Opal on Santa Rosa Island, Florida." J. Coastal Res., 17(4): 936-948.

Miller, K.G., R.E. Kopp, B.P. Horton, J.V. Browning, and A.C. Kemp, 2013. "A geological perspective on sea-level rise and impacts along the U.S. mid-Atlantic coast.: Earth's Future 1(1):3-18.

Millington, J.A., C.A. Booth, M.A. Fullen, G.M. Moore, I.C. Trueman, A.T. Worsley, N. Richardson, and E. Baltrenaite, 2009. "The role of long-term landscape photography as a tool in dune management." J. of Environ. Engineering and Landscape Management 17(4): la-lh.

Nordstrom, K.F., and N.L. Jackson, 2013. "Foredune Restoration in Urban Settings." In: Martínez LM, Gallego-Fernández JB, Hesp PA (eds) Restoration of Coastal Dunes. Springer, New York, pp 17-32.

Nuwer, R. 2012. "Sand Dunes Alone Will Not Save the Day." The New York Times, NYC. December 4, 2012. Web. $<$ http://green. blogs. nytimes.com/2012/12/04/sand-dunes-alonewill-not-save-the-day/?_r $=0>$ (Accessed July 29, 2013).fnuw

Ruz, M.H., and E.J. Anthony, 2008. "Sand trapping by brushwood fences on a beach-foredune contact: the primacy of the local sediment budget." Zeitschrift Fur Geomorphologie, Supplementary Issue S52(3):179-194.

Savage, R.P., 1962. "Experimental study of dune building with sand fences. Proceedings of the $8^{\text {th }}$ Coastal Engineering Conference. Council on Wave Research, 380-396.

Savage, R.P., and W.W. Woodhouse Jr., 1968 "Creation and Stabilization of Coastal Barrier Dunes." Proc. 11th Conf. on Coastal Eng., ASCE, 671-700.

Saye, S.E., D. van der Wal, K. Pye, and S.J. Blott, 2005. "Beach-dune morphological relationships and erosion/accretion: An investigation at five sites in England and Wales using LIDAR data." Geomorphology 72(1-4):128-155.

Silva R., M.L. Martínez, I. Odéiz, E. Mendoza, and R.A. Feagin, 2016. "Response of vegetated dune-beach systems to storm conditions." Coastal Engineering 109: 53-62.

U.S. Census Bureau, 2010. "State and County Quickfacts - New Jersey." U.S. Census 2010. http://quickfacts.census.gov/qfd/ states/34000.html. Accessed 27 June 2013.

Woodhouse, W.W. Jr., 1978. "Dune building and stabilization with vegetation." Fort Belvoir, VA: U.S. Army Corps of Engineers, Coastal Engineering Research Center, SR-3.

Wootton, L.S., S.D. Halsey, K. Bevaart, A. McGough, J. Ondreicka, and P. Patel, 2005. "When invasive species have benefits as well as costs: maganging Carex kobomugi (Asiatic sand sedge) in New Jersey's coastal dunes." Biological Invasions 7:1017-1027. 